\title{
Inhalation and skin tests with extracts of hay and fungi in patients with farmer's lung
}

\author{
J. V. W I L L I A M S
}

\author{
From the Institute of Diseases of the Chest, and Brompton Hospital, London
}

Farmer's lung is a specific respiratory illness which results from the inhalation of mouldy hay, grain, straw, or other similar vegetable matter. Hay becomes mouldy if it is harvested and stored wet. Fungi and bacteria multiply in it, fermentation occurs, and heat is produced. When dry, the mouldy hay is partly converted to a fine dust. The illness was described by Campbell in 1932 and later by Fawcitt (1936a and b, 1938a and b), Fuller (1953), Studdert (1953), Frank (1958), and Dickie and Rankin (1958). It is fairly common in Britain (Staines and Forman, 1961).

Acute, subacute, and chronic phases of the illness have been described by Fuller (1953). The acute illness is characterized by dyspnoea, cough, fever, malaise, cyanosis, basal crepitations, and later diffuse reticulo-nodular chest radiographic shadowing. The pulmonary histological changes consist of a granulomatous infiltration of the interstitial tissues with no evidence of bacterial or fungal proliferation. Later pulmonary fibrosis, distortion of the bronchioles, and emphysema occur (Fuller, 1953 and 1958; Frank, 1958; Dickie and Rankin, 1958 ; Totten, Reid, Davis, and Moran, 1958; Seal, 1962).

The acute symptoms which occur after exposure to mouldy hay have been attributed to a bronchomycosis (Fawcitt, 1936a and b; Törnell, 1946), mechanical blockage of the pulmonary airways by the swelling or germination of fungal spores (Williams and Mulhall, 1956; Pickworth, 1961), non-specific pulmonary irritation (Studdert, 1953), the toxic effect of a mould in a non-allergic person (Frankland and Hamilton, 1958), a hypersensitivity reaction to fungi or their products (Fawcitt, 1938a and b; Dickie and Rankin, 1958; Cooper and Greenaway, 1961), the physical, chemical, or immunological properties of the fine degraded hay fibre which has been acted on by the mouldy hay microflora (Duncan, 1945), and the inhalation of bacterial endotoxins (Pernis, Vigliani, Cavagna, and Finueli, 1961).

This report describes skin and inhalation tests with crude hay and extracts of hay and fungi on patients with farmer's lung and other conditions. The purpose of the investigation was twofold: to investigate the relation between exposure to hay dust and symptoms in patients thought to be suffering from farmer's lung, and to obtain new information on the aetiology, pulmonary 을 physiology, treatment, and diagnosis of the $\rightarrow$ condition.

\section{CLINICAL MATERIAL}

Three groups of patients were studied.

FARMER'S LUNG PATIENTS The 16 patients with farmer's lung had all worked on farms in south-west England since childhood, except one patient who had kept a dairy farm for 10 years only. Their ages ranged from 25 to 57 years. There were five women in the group. They all fulfilled the following diagnostic criteria:

1. Symptoms should appear within 36 hours after the inhalation of mouldy vegetable dust (e.g., hay, corn, and grain).

2. Dyspnoea should be a prominent symptom.

3. Crepitations rather than rhonchi should be heard on auscultation of the chest during the acute illness. Where adventitious sounds are not heard, 'wheeze' should not have been a prominent symptom. This distinguishes the condition from 'asthma', which is characterized by paroxysms of dyspnoea accompanied by wheezing.

4. Where chest radiographs are available during or 음 just after the acute illness, they should show bilateral $\underset{D}{D}$ diffuse reticulo-nodular shadowing. (Such films were available in 15 of the 16 patients.)

5. Positive findings diagnostic of other diseases $N$ should not be present (e.g., pulmonary tuberculosis and specific bacterial pneumonia).

No patient had a past or family history of asthma, $\omega$ hay fever, urticaria, or infantile eczema. Blood $\underset{\gamma}{ }$ haemoglobin, total white counts, and absolute 0 eosinophil counts were all normal, as were the $\frac{\mathscr{D}}{\mathscr{C}}$ electrocardiograms. Out of 14 patients, 10 had nega- 只 tive tuberculin tests to 100 T.U. $(71 \%)$, two reacted $\square$ to 100 T.U. (14\%), and two reacted to 10 T.U. (14\%). One of the negative reactors had evidence of an old $\overrightarrow{\mathbb{D}}$ calcified primary tuberculous complex on the chest $\frac{O}{\mathbb{D}}$ radiograph, and another had had tuberculous cervical lymph nodes removed when a child. 
When they had recovered from their acute illnesses and had felt relatively well for three weeks, they were admitted to hospital for study. The aims of the tests were explained to each patient.

CONTROLS Forty-four people who clinically did not have farmer's lung or allergic asthma were tested in a similar manner to the patients with farmer's lung.

ALlergic asthmatics Thirty-eight patients with asthma and evidence that specific, extrinsic allergic factors were contributory to their disability were also tested. The evidence was obtained from the clinical history, positive skin tests, and positive inhalation tests to certain allergens.

\section{MATERIALS AND METHODS}

\section{TEST EXTRACTS The following were obtained.}

Hay extracts (a) Eleven specimens of mouldy hay were obtained from farmer's lung patients. Each was defatted with acetone overnight. After decantation of the acetone, the product was treated with $0.5 \%$ carbol-saline solution. This was added in the approximate proportion of $10 \% \mathrm{w} / \mathrm{v}$, and the suspension was allowed to stand at room temperature for five days. The extracting fluid was filtered and dialysed against tap water for 24 hours. It was then Seitzfiltered and a filter was used which only allowed particles smaller than $0.7 \mu$ to pass through. Bacteria, spores, and other particulate matter were thus removed. The solutions obtained could be freeze-dried and reconstituted quantitatively into solutions of different strengths. A $1 \% \mathrm{w} / \mathrm{v}$ concentration of the freeze-dried extract was the strength commonly used.

(b) Dr. P. H. Gregory supplied fractions of mouldy hay from the Rothamsted Experimental Station. This hay had been fractionated according to particle size using a 'wind tunnel'. In this technique a current of air passes over the hay specimen and blows the hay particles along a tube, the lighter particles travelling further than the heavier particles. In this way 'fine', 'medium', 'coarse', and 'extra-coarse' fractions of mouldy hay were obtained, depending on their approximate particle size. Extracts of these fractions were made as in $(a)$, and $1 \% \mathrm{w} / \mathrm{v}$ solutions were obtained.

(c) A specimen of 'good' or 'clean' hay was extracted as in (a).

(d) 'Good' hay was autoclaved for 15 minutes under $15 \mathrm{lb}$. per square inch pressure. It was then treated as in $(a)$.

(e) Samples of 'good' hay were placed in Kilner jars to which were added heavy inocula of Mucor (sp.) and Aspergillus fumigatus, separately. They were left at room temperature for three weeks and the hay was then treated as in $(a)$.

Mould extracts Four-week-old cultures of $A$. fumigatus, $A$. terreus, $A$. nidulans, A. niger, A. flavus, Cladosporium herbarum, and Mucor (sp.) were prepared on Sabouraud's broth in Thomsen bottles. The mycelium was washed with saline to remove the medium, and then the cell sap was obtained by crushing the mycelium in a mixer. The sap was filtered, Seitz-filtered, dialysed, and freeze-dried. The extracts were then reconstituted into $1 \% \mathrm{w} / \mathrm{v}$ solutions.

Candida albicans was grown for six weeks at room temperature. The white suspension was filtered, and the filtrate was Seitz-filtered, dialysed, freeze-dried, and then reconstituted into a $1 \% \mathrm{w} / \mathrm{v}$ solution.

Ten per cent $\mathrm{w} / \mathrm{v}$ extracts of $A$. fumigatus, Penicillium, Alternaria, and Cladosporium were made in a similar manner to the hay extracts.

Other extracts Ten per cent $\mathrm{w} / \mathrm{v}$ extracts of house dust and $1 \% \mathrm{w} / \mathrm{v}$ extracts of grass pollen, made in a similar manner to the hay extracts, were also obtained.

THE PRODUCTION OF AEROSOls Aerosols were made from solutions of the extracts using a Wright nebulizer (Wright, 1958) and air under $20 \mathrm{lb}$. per square inch pressure from a cylinder. The patient inhaled the aerosol through a simple face mask connected to a rebreathing bag. Patients were told to breathe normally during this procedure. If the cylinder air pressure, the volume, temperature, and concentration of the extract were all constant, it was assumed that approximately equal quantities of the same extract would be inhaled by the same patient in the same time.

TECHNIQUE OF INHALATION TESTS WITH AEROSOLS The effects produced on the patient after inhaling an aerosol of the extract under investigation were compared with those obtained after inhalation of the extracting fluid, $0.5 \%$ carbol saline, on a different day. Clinical and physiological studies were made before and after the inhalations (usually five minutes afterwards and then hourly). The following were studied:

1. The symptoms produced

2. Chest auscultatory signs

3. Temperature, pulse, and respiratory rates

4. Forced expiratory volume in one second (F.E.V.1) and forced vital capacity (F.V.C.). These were measured using a low resistance spirometer of the type described by Bernstein, D'Silva, and Mendel (1952). The mean of three consistent readings was taken. The maximum voluntary ventilation (M.V.V.) was measured using this spirometer, the patient breathing in time with a metronome at rates of 50 , 60 , and 70 breaths per minute. The highest result was recorded

5. Peak expiratory flow rate (P.E.F.R.) measured using the peak flow meter described by Wright and McKerrow (1959)

6. The effect of inhalation of an isoprenaline aerosol on the F.E.V.1 and F.V.C.

7. Resting minute volume (M.V.) measured by a Wright anemometer (Wright, 1955)

8. Static lung compliance from transpulmonary 
pressure and tidal volume estimations. The method used was the same as that used by Davies, Williams, and Wood (1962)

9. Steady-state carbon monoxide diffusing capacity $\left(D_{\mathrm{co}}\right)$ by the method used by Macnamara, Prime, and Sinclair (1959)

10. White blood counts and absolute eosinophil counts

11. Chest radiographs.

All these studies could not be made during each inhalation test. Close observation of the patient was essential. The aerosols were given for a period of time to each patient starting with 10 seconds and then increasing on different days up to seven minutes, if no untoward symptoms had occurred. The term 'farmer's lung reaction' or 'reaction' was used if the symptoms of the acute illness of farmer's lung appeared after the inhalation of hay extract but not after the similar inhalation of carbol saline solution on a different day (although in each test the patient thought that hay was inhaled). If objective evidence of a disturbance in function was not obtained in a 'reaction', the test was usually repeated on a different day, using a slightly larger dose of hay extract, unless the original symptoms had been severe.

TECHNIQUE OF INHALATION TESTS WITH CRUDE HAY DUST A mask containing loosely packed mouldy hay dust was made by wrapping the dust in several layers of dressing gauze. The mask was applied to the patient's mouth for up to 20 minutes, and a nose clip ensured that he breathed entirely through the gauze. The contents of the mask could not be seen or smelt by the patient. If a reaction was suspected, the test was repeated on a different day in a similar manner except that, unknown to the patient, wood shavings were used instead of mouldy hay dust.

ISOLATION AND IDENTIFICATION OF FUNGI A specimen of each mouldy hay was inoculated into six Sabouraud dextrose-agar plates. Two were kept at room temperature and four at $37^{\circ} \mathrm{C}$. The plates were retained for up to seven days.

Sputum was examined by the method used by Pepys, Riddell, Citron, Clayton, and Short (1959).

The further identification of each culture was carried out by microscopy of smears stained with Lactophenol blue.

SKIN TESTS Both prick skin tests and the intradermal injection of $0.1 \mathrm{ml}$. of extract were made. The extracting fluid, $0.5 \%$ carbol saline solution, was the control. The tests were read after 10 minutes, one hour, six hours, 24 hours, and 72 hours. Weals which were larger than those produced by the control solution were regarded as positive.

\section{RESULTS}

The fungi isolated on Sabouraud's medium from mouldy hay and from the sputum of farmer's lung patients are shown in Tables I and II respectively.
T A B L E I

FUNGI ISOLATED ON SABOURAUD'S MEDIUM FROMO MOULDY HAY

\begin{tabular}{lc} 
& $\begin{array}{c}\text { No. of Mouldy Hay } \\
\text { Specimens Found } \\
\text { (Total of 11) }\end{array}$ \\
\hline Mucor (sp.) & 11 \\
Penicillium (sp.) & 11 \\
A. fumigatus & 10 \\
A. terreus & 3 \\
A. nidulans & 2 \\
A. niger & 1 \\
A. versicolor & 1 \\
Scopulariopsis & 1 \\
Yeasts & 1
\end{tabular}

T A B L E I I

FUNGI ISOLATED FROM SPUTUM SPECIMENS OF FARMER'S LUNG PATIENTS

\begin{tabular}{lc} 
& $\begin{array}{c}\text { No. of Specimens } \\
\text { Present }\end{array}$ \\
\hline C. albicans & 5 \\
A. fumigatus & 3 \\
Mucor (sp.) & 1 \\
Fusat ium & 1
\end{tabular}

134 specimens obtained from nine patients

SKIN TESTS

Both prick and intradermal skin tests with $1 \%$ $w / v$ extracts of various mouldy hay extracts were made on 16 farmer's lung patients, 30 normalo controls, and 10 allergic asthmatics. Hay extract $\varrho$ was mildly irritant, and non-specific weals $\overrightarrow{\hat{0}}$ appeared minutes after the injection. Delayed 3 reactions were not seen. The skin reactions in farmer's lung patients and normal controls were? similar, though the reactions in the allergic asthmatics were larger than these (Table III).

T A B L E I I I

PRICK SKIN TESTS WITH MOULDY HAY EXTRACTS

\begin{tabular}{|c|c|c|c|c|c|c|}
\hline \multirow[b]{2}{*}{$\begin{array}{l}\text { Hay } \\
\text { Extract } \\
1 \%\end{array}$} & \multicolumn{2}{|c|}{$\begin{array}{l}\text { Farmer's Lung } \\
\text { Patients }\end{array}$} & \multicolumn{2}{|l|}{$\begin{array}{l}\text { Normal } \\
\text { Controls }\end{array}$} & \multicolumn{2}{|c|}{$\begin{array}{l}\text { Allergic } \\
\text { Asthmatics }\end{array}$} \\
\hline & $\begin{array}{l}\text { Average } \\
\text { Weal }^{1}\end{array}$ & $\begin{array}{l}\text { No. of } \\
\text { Patients } \\
\text { Tested }\end{array}$ & $\begin{array}{l}\text { Average } \\
\text { Weal }^{1}\end{array}$ & $\begin{array}{l}\text { No. of } \\
\text { Patients } \\
\text { Tested }\end{array}$ & $\underset{\text { Weal }^{1}}{\text { Average }}$ & $\begin{array}{l}\text { No. of } \\
\text { Patients } \\
\text { Tested }\end{array}$ \\
\hline $\begin{array}{l}1 \\
2 \\
3 \\
4 \\
5 \\
6 \\
7 \\
8 \\
9 \\
10 \\
11 \\
\text { 'Good hay' } \\
\text { 'Autoclaved }\end{array}$ & $\begin{array}{l}2 \\
2 \\
2 \\
1 \frac{1}{2} \\
2 \frac{1}{2} \\
2 \\
2 \\
2 \\
2 \\
2 \\
2 \frac{1}{2} \\
2\end{array}$ & $\begin{array}{r}15 \\
11 \\
7 \\
6 \\
13 \\
8 \\
12 \\
9 \\
9 \\
9 \\
5 \\
5\end{array}$ & $\begin{array}{l}2 \\
2 \\
2 \\
2 \\
2 \frac{1}{2} \\
2 \\
2 \\
1 \frac{1}{2} \\
2 \\
2 \\
2 \\
2\end{array}$ & $\begin{array}{l}18 \\
18 \\
18 \\
18 \\
18 \\
18 \\
16 \\
14 \\
14 \\
14 \\
14 \\
13\end{array}$ & $\begin{array}{l}3 \frac{1}{2} \\
4 \\
4 \\
4\end{array}$ & $\begin{array}{l}10 \\
10 \\
10 \\
10\end{array}$ \\
\hline $\begin{array}{l}\text { good hay' } \\
\text { 'Aspergillus } \\
\text { inoculated }\end{array}$ & 2 & 5 & 2 & 13 & & \\
\hline $\begin{array}{l}\text { good hay' } \\
\text { 'Mucor } \\
\text { inoculated } \\
\text { good hay' }\end{array}$ & 2 & 3 & & 12 & & \\
\hline
\end{tabular}

1Size of weal is represented here as the number of times it was larger than the carbol saline control when read at 10 minutes 
Prick skin tests with $1 \%$ extracts of $A$. fumigatus, $A$. terreus, $A$. nidulans, $A$. niger, $A$. flavus, Cladosporium herbarum, Penicillium (sp.), Mucor (sp.), Alternaria, grass pollen, and house dust were negative in both farmer's lung patients and normal controls, though positive results were obtained in allergic asthmatics (Table IV). The

\section{T A B LE I V}

SUMMARY OF PRICK SKIN TESTS WITH EXTRACTS OF FUNGI, ETC., ON FARMER'S LUNG PATIENTS

\begin{tabular}{|c|c|c|}
\hline $1 \%$ Extract & $\begin{array}{l}\text { No. of } \\
\text { Farmer's } \\
\text { Lung } \\
\text { Patients } \\
\text { Tested }\end{array}$ & $\begin{array}{l}\text { Comments } \\
\text { ( } 38 \text { 'allergic' asthmatics } \\
\text { studied) }\end{array}$ \\
\hline $\begin{array}{l}\text { A. fumigatus } \\
\text { A. terreus } \\
\text { A. niger } \\
\text { A. nidulans } \\
\text { A. flavus } \\
\text { Penicillium } \\
\text { Mucor (sp.) } \\
\text { Candida albicans }\end{array}$ & $\begin{array}{r}16 \\
5 \\
5 \\
5 \\
5 \\
16 \\
15 \\
16\end{array}$ & $\begin{array}{l}\text { Positive in } 17 \text { asthmatics } \\
\text { Positive in } 17 \text { asthmatics } \\
\text { Positive in } 17 \text { asthmatics } \\
\text { Positive in } 17 \text { asthmatics } \\
\text { Positive in } 17 \text { asthmatics } \\
\text { Positive in } 3 \text { asthmatics } \\
\text { Positive in } 2 \text { asthmatics } \\
\text { Positive in } 13 \text { out of } 35\end{array}$ \\
\hline $\begin{array}{l}\text { Alternaria } \\
\text { Cladosporium } \\
\text { Merulius } \\
\text { Grass pollen } \\
\text { House dust }\end{array}$ & $\begin{array}{l}16 \\
16 \\
16 \\
16 \\
16\end{array}$ & $\begin{array}{l}\text { Positive in } 12 \text { asthmatics } \\
\text { Positive in } 12 \text { asthmatics } \\
\text { Positive in } 10 \text { asthmatics } \\
\text { Positive in } 20 \text { asthmatics } \\
\text { Positive in } 18 \text { asthmatics }\end{array}$ \\
\hline
\end{tabular}

All skin tests were negative in farmer's lung patients except in the case of Candida albicans where one farmer's lung patient reacted immediately

skin tests to Candida albicans extracts produced one out of 16 positive reactions in farmer's lung patients and 13 out of 35 positive reactions in asthmatics and normal controls.

\section{INHALATION TESTS ON FARMER'S LUNG PATIENTS}

MOULDY HAY DUST A patient inhaled mouldy hay dust for five minutes through a gauze mask. Nothing happened, and the test was repeated on the following day with 20 minutes' exposure to the hay dust. Immediately after the second inhalation no symptoms appeared, and the vital capacity was unchanged. Four and a half hours later the patient felt unwell with slight effort dyspnoea, a nonproductive cough, fatigue, and slight shivering. Nine and a half hours after the inhalation he began to perspire profusely. His vital capacity was consistently 3.8 litres before the inhalation whereas four and a half hours later it had fallen slightly to 3.4 litres. His temperature nine hours after the inhalation was $99 \cdot 6^{\circ} \mathrm{F} .\left(37 \cdot 5^{\circ} \mathrm{C}\right.$.) whereas before the test it was $98 \cdot 0^{\circ} \mathrm{F}$. $\left(36.7^{\circ} \mathrm{C}\right.$.). He had not been feverish for at least two weeks before this. He insisted that his symptoms were similar to those he had noticed after handling mouldy hay in his barn. They lasted six hours and he felt fit the following day. No abnormal physical signs were noted in the chest. The repetition of the test on another day using wood shavings instead of mouldy hay dust in the mask, unknown to the patient, produced no symptoms and signs. This test confirmed that the patient was sensitive to mouldy hay dust.

MOULDY HAY EXTRACTS Fourteen farmer's lung patients were tested, of whom nine reacted to aerosols of the extracts a few hours later, one a few minutes later, and one probably 26 hours later. A further analysis of the data obtained from the patients who reacted a few hours after exposure to the extract is given. Repeated exposures to hay extract caused further reactions and so 18 reactions were studied. The same hay extract caused a reaction five and a half hours after inhalation (twice) in one patient, and 10 to 13 hours afterwards (twice) in another.

Clinical description of a typical reaction A patient inhaled an aerosol of mouldy hay extract for six minutes. He felt well immediately after this and there was no nasal or pharyngeal irritation. Four hours later he felt tired and about an hour afterwards he became shivery and then hot. He had a persistent, throbbing, frontal headache. He was more dyspnoeic on exertion than before the test though he was not dyspnoeic at rest. Six hours after the inhalation he noticed palpitations, i.e., a rapid, regular, and forceful beating of his heart. He complained of cough but this was not a prominent symptom. The symptoms subsided gradually and had disappeared six hours after their onset. He maintained they were the same as those symptoms he had felt at home after handling mouldy hay at work.

His temperature, pulse, and respiration charts after the inhalation of mouldy hay extract and a control solution on different days are shown in Figure 1. The temperature started rising about five hours after the inhalation of hay extract, it remained elevated for about nine hours, and the highest temperature recorded was $101 \cdot 4^{\circ} \mathrm{F}$. $\left(38.6^{\circ} \mathrm{C}\right.$.). The pulse and respiratory rates also rose.

Repeated chest auscultation showed that basal crepitations appeared five and a half hours after the inhalation and they were present for 16 hours. No rhonchi were heard during the reaction. There was no evidence of right-sided heart failure.

Symptoms during reactions Nothing abnormal was noticed by the nine patients immediately after the inhalations, and there was no change in physical signs. Symptoms and signs appeared gradually between three and eight and a half hours afterwards and usually lasted from four to 24 hours. 


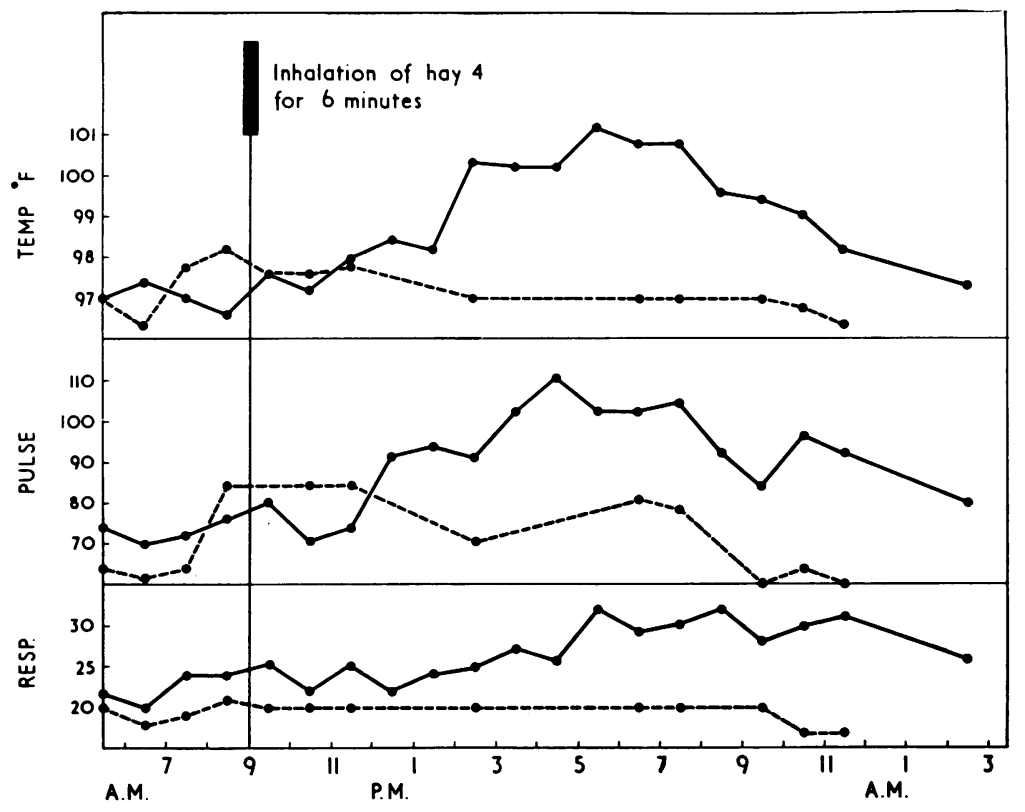

FIG. 1. Temperature, pulse, and $\vec{\circ}$ respiration charts of a farmer's $\overrightarrow{\vec{B}}$ lung patient during inhalation $\vec{\omega}$ tests: $-=$ after the inhalation of an aerosol of a $1 \%$ solution of mouldy hay extract $\vec{\infty}$ for six minutes ; - - - = afteri the inhalation of $0.5 \%$ carbol $\rightarrow$ saline (Coca) solution for six minutes on a different day.
Table $\mathrm{V}$ shows the more prominent symptoms. Malaise, fatigue, and anorexia were always the first to appear. They were usually followed about an hour later by the patient feeling shivery and then hot. This symptom occurred even if no fever was found. Five patients complained of slight dyspnoea at rest, but all had increased effort dyspnoea in reactions. No patient complained of pleuritic chest pain, but five had a retrosternal sensation of tightness.

All but one patient volunteered that the induced reaction was the illness they had known after working with mouldy hay. The other patient stated that the reaction was similar to his previous illness, but general symptoms were more prominent in the induced reaction.

\section{T A B LE V}

SYMPTOMS, ETC., IN REACTIONS IN NINE PATIENTS STUDIED

No. of Patients

Malaise, fatigue, anorexia

Feeling shivery and then hot

Non-productive cough

Dyspnoea at rest

Chest tightness and retrosternal heaviness

Palpitations

Nasal and pharyngeal congestion

Headache

Tremor

Nausea

Muscle aches

Similarity of 'reaction' to illness on farm

Appearance of crepitations
Temperature, pulse, and respirations Six of the nine patients became feverish after the $\varrho$ inhalation of mouldy hay extract. The temperature $\vec{\overrightarrow{ }}$ started to rise five to six hours after the inhalation 3 in nine tests and in three it was 10 to 13 hours afterwards. The highest temperatures recorded? varied from $99 \cdot 6^{\circ} \mathrm{F}$. to $103^{\circ} \mathrm{F}$. $\left(37 \cdot 5\right.$ to $39 \cdot 4^{\circ} \mathrm{C}$.). The fever usually lasted six hours (range three to응 18 hours). It usually subsided gradually over three $\tilde{x}$ to four hours. The pulse and respiratory rates rose with the fever. Electrocardiograms taken in two reactions showed the increase in heart rate 0 to be a sinus tachycardia.

Physical examination Repeated chest ausculta-옹 tion showed that basal crepitations appeared in 11D out of 16 reactions. They were first heard at about the same time as the fever and persisted for up ton 24 hours. Rhonchi were not heard in reactions. Two patients had slight central cyanosis during a reaction.

Other investigations A blood leucocytosis of over $12,000 / \mathrm{c} . \mathrm{mm}$. occurred in six out of 110 reactions (Table VI). No significant change was $\overparen{\Phi}$ seen in the absolute eosinophil counts. Chest $\stackrel{?}{+}$ radiographs taken after reactions had not altered 0 when compared with those taken before.

Pulmonary function studies The main changes during reactions are shown in Table VII.

A slight but definite fall in F.E.V., F.V.C., 0 M.V.V., and P.E.F.R. occurred (Figs. 2, 3, and 4). 


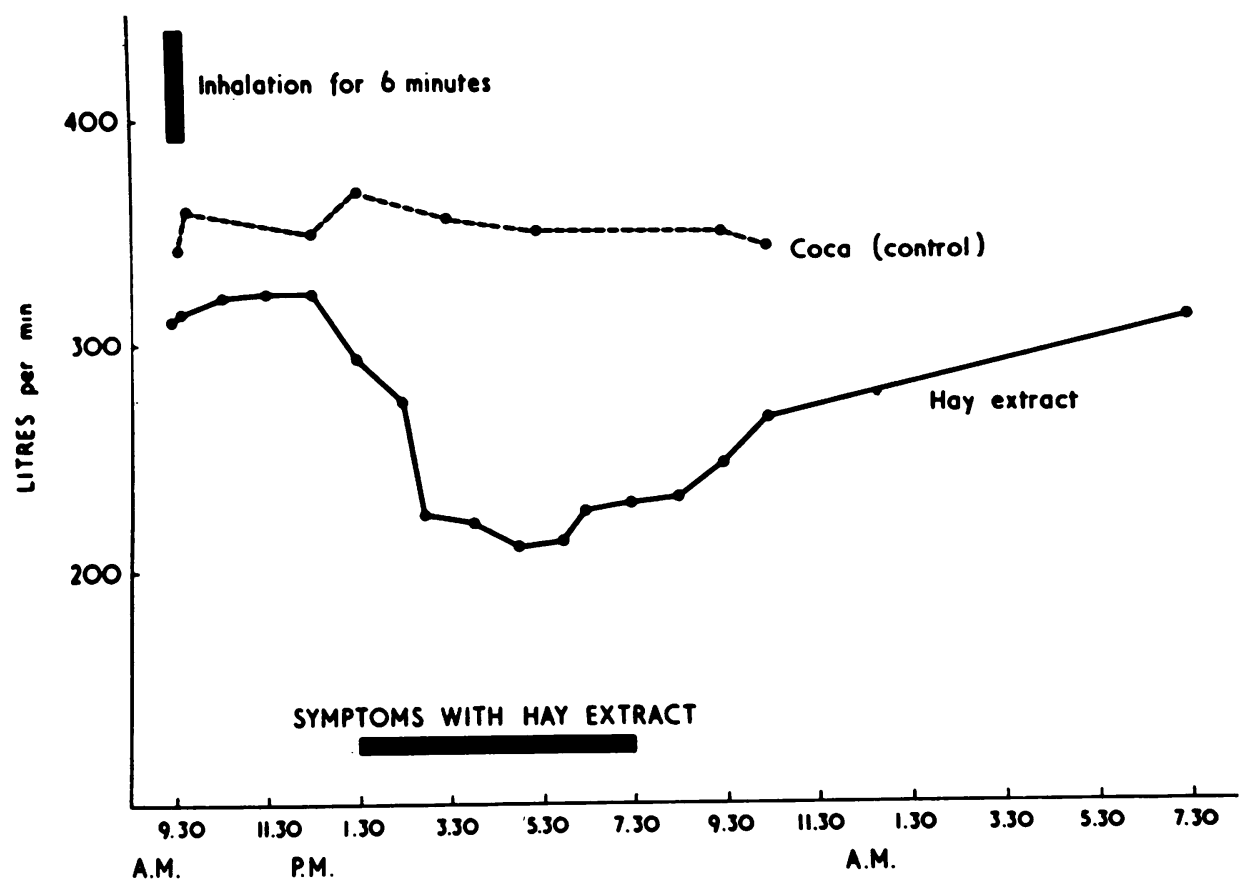

FIG. 2. Peak expiratory flow rates in a patient with farmer's lung after the inhalation of mouldy hay extract for six minutes and $0.5 \%$ carbol saline (Coca) solution on a different day also for six minutes.

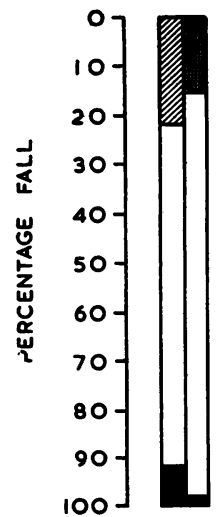

REACTION NO.2

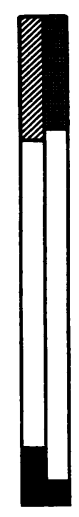

3
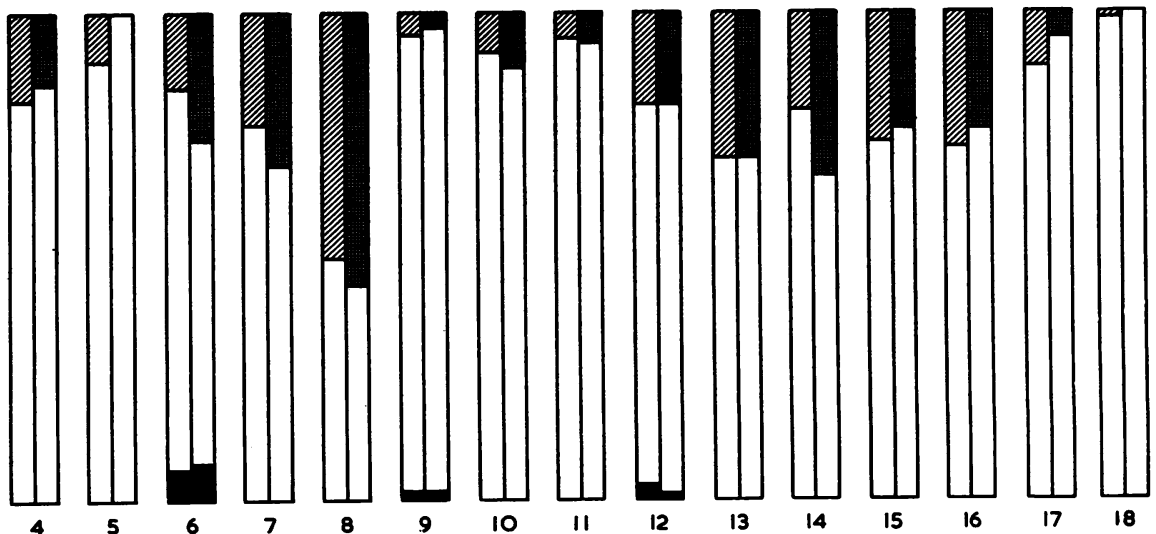

FIG. 3. Changes in F.E.V., and F.V.C. in farmer's lung reactions expressed as a percentage of the original value: each set of columns = F.E.V.1 (left) and F.V.C. (right) in a particular reaction; the whole column = original figure before the reaction $=100 \% ;$ the shaded areas at top $=\%$ falls at height of a reaction; the shaded areas at bottom $=\%$ improvement after an aerosol of isoprenaline (measured in reactions $2,3,6,9,12$ and 16). 
T A B LE VI

BLOOD EOSINOPHILS AND TOTAL WHITE COUNTS IN REACTIONS

\begin{tabular}{|c|c|c|c|c|}
\hline Patient & $\begin{array}{l}\text { No. of } \\
\text { Reaction }\end{array}$ & $\begin{array}{l}\text { Blood } \\
\text { Eosinophils } \\
\text { (per c.mm.) }\end{array}$ & $\begin{array}{l}\text { Total White } \\
\text { Blood Count } \\
\text { (per c.mm.) }\end{array}$ & $\begin{array}{l}\text { Time of } \\
\text { Observation } \\
\text { (hours after } \\
\text { inhalation) }\end{array}$ \\
\hline 1 & 2 & $\begin{array}{l}110 \\
180 \\
160\end{array}$ & $\begin{array}{l}7,000 \\
9,400 \\
7,400\end{array}$ & $\begin{array}{r}0 \\
4 \\
24\end{array}$ \\
\hline \multirow[t]{4}{*}{2} & 3 & $\begin{array}{l}70 \\
60\end{array}$ & $\begin{array}{r}9,000 \\
10,500\end{array}$ & $\begin{array}{r}0 \\
24\end{array}$ \\
\hline & 6 & $\begin{array}{r}90 \\
110 \\
90 \\
60\end{array}$ & $\begin{array}{r}8,000 \\
14,000 \\
16,000 \\
9,000\end{array}$ & $\begin{array}{r}0 \\
6 \\
8 \\
24\end{array}$ \\
\hline & 7 & $\begin{array}{r}80 \\
60 \\
110 \\
100\end{array}$ & $\begin{array}{r}9,200 \\
16.000 \\
17,000 \\
10,000\end{array}$ & $\begin{array}{r}0 \\
5 \\
8 \\
24\end{array}$ \\
\hline & Control & $\begin{array}{r}100 \\
110 \\
120 \\
50\end{array}$ & $\begin{array}{r}9,000 \\
8,000 \\
10,000 \\
9,000\end{array}$ & $\begin{array}{r}0 \\
6 \\
8 \\
24\end{array}$ \\
\hline 3 & 8 & $\begin{array}{l}210 \\
250 \\
180\end{array}$ & $\begin{array}{r}6.400 \\
12.000 \\
8.600\end{array}$ & $\begin{array}{r}0 \\
3 \\
21\end{array}$ \\
\hline 4 & 9 & $\begin{array}{r}140 \\
50\end{array}$ & $\begin{array}{l}4,800 \\
9.700\end{array}$ & $\begin{array}{r}0 \\
21\end{array}$ \\
\hline 5 & 10 & $\begin{array}{l}70 \\
50 \\
50\end{array}$ & $\begin{array}{l}5.800 \\
5,200 \\
6.000\end{array}$ & $\begin{array}{r}0 \\
3 \\
21\end{array}$ \\
\hline 6 & 12 & $\begin{array}{r}170 \\
180 \\
340 \\
50 \\
180 \\
70\end{array}$ & $\begin{array}{r}7,000 \\
11,000 \\
7,000 \\
9,500 \\
7,500 \\
10,500\end{array}$ & $\begin{array}{r}0 \\
1 \\
3 \\
5 \\
6 \\
23\end{array}$ \\
\hline \multirow[t]{2}{*}{8} & 15 & $\begin{array}{r}60 \\
100\end{array}$ & $\begin{array}{l}10,000 \\
14,000\end{array}$ & $\begin{array}{r}0 \\
24\end{array}$ \\
\hline & 16 & $\begin{array}{l}100 \\
170 \\
130\end{array}$ & $\begin{array}{r}6.000 \\
14,000 \\
12,500\end{array}$ & $\begin{array}{r}0 \\
7 \\
25\end{array}$ \\
\hline 9 & 18 & $\begin{array}{l}100 \\
150\end{array}$ & $\begin{array}{l}10,000 \\
16.500\end{array}$ & $\begin{array}{l}0 \\
5\end{array}$ \\
\hline
\end{tabular}

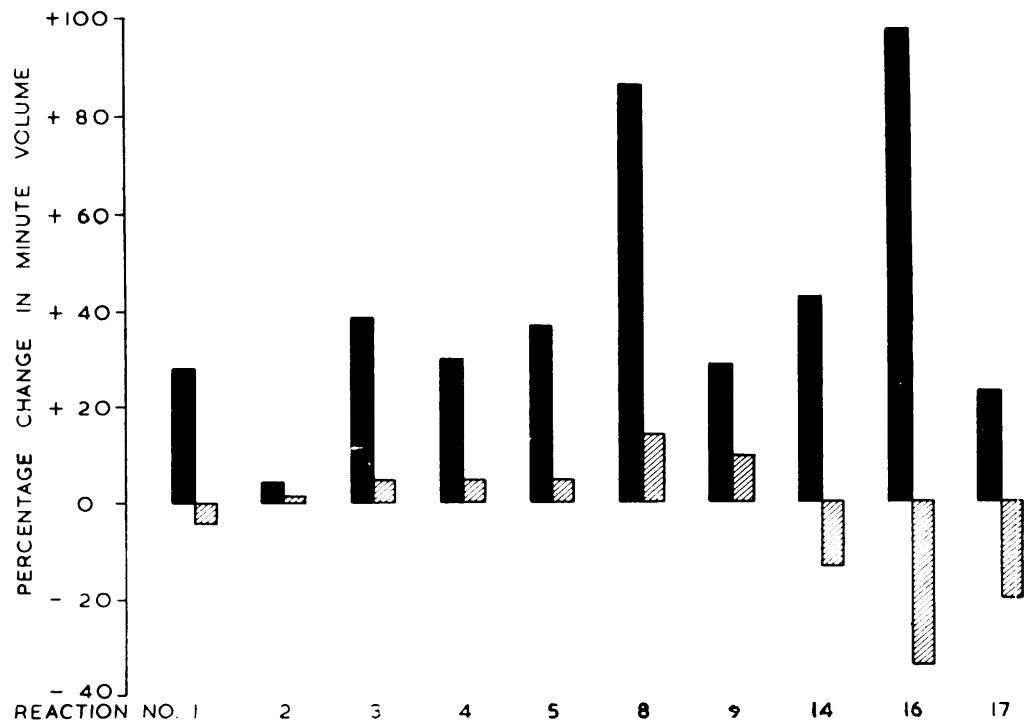

T A B LE VII

CHANGES IN LUNG FUNCTION STUDIES IN REACTIONS

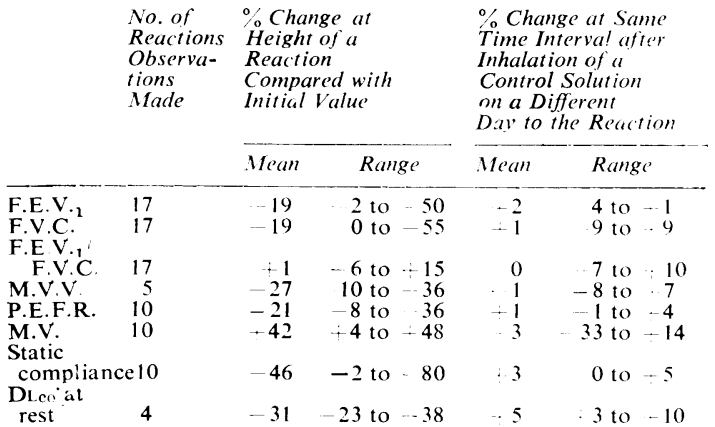
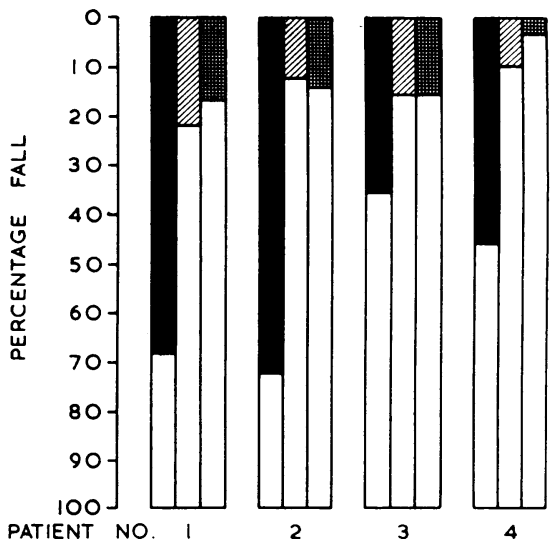

FIG. 4

FIG. 4. Percentage falls, during farmer's lung reactions, of static lung compliance (left) : F.E.V. (middle); and F.V.C. (right column).

FIG. 5. Percentage change in minute volume in farmer's lung reactions compared with changes after inhalation of a control solution. In each pair of stacks, left $={ }_{0}^{\circ}$ change in reaction; right $={ }^{\circ}$ change after inhalation of a carbol saline control solution for same time as mouldy. hay extract, but on a different day (measured at same time interval after inhalation of mouldy hav extract). 
AFTER REACTIONS
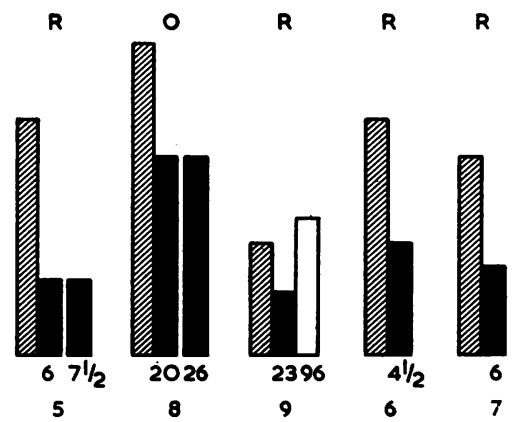

$O=R A \hat{L E S S}$ NOT HEARD $R=R A ̂ L E S$ APPEARED
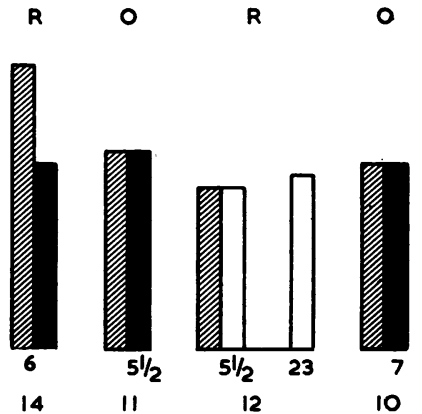

FIG. 6. Static compliance changes in reactions $\left(\mathrm{l} . / \mathrm{cm} . \mathrm{H}_{2} \mathrm{O}\right)$. First column in each group is the estimation before the inhalation test. The numbers immediately bolow columns refer to the number of hours after inhalation the observation was made.

The ratio F.E.V. ${ }_{1}$ /F.V.C. did not alter appreciably in reactions ; the mean was $84 \%$ before and $85 \%$ during 17 reactions. The inhalation of a $1 \%$ isoprenaline aerosol for 20 seconds had little effect on the F.E.V..$_{1}$ and F.V.C. The F.E.V..$_{1}$ increased by a mean of $5 \%$ only and F.V.C. by $3 \%$ in six reactions. Bronchial airway obstruction which may be reversed by isoprenaline was therefore not significant. The fall in ventilatory function usually appeared five to six hours after the inhalation and had usually disappeared within 24 hours.

The M.V. rose in all 10 reactions in which it was measured (Fig. 5).

The static lung compliance estimations are shown in Figure 6. A marked fall was observed in nine reactions. In three reactions there was little change. Of these, reactions 10 and 11 were mild and characterized by symptoms only; reaction 12 was typical but unfortunately compliance estimations were not obtained at the height of the reaction. Crepitations were heard on chest auscultation where a compliance change occurred. Compliance fell more than the F.E.V., and F.V.C. (Fig. 4).

Comparable results of the diffusing capacity for carbon monoxide $\left(\mathrm{DL}_{\mathrm{co}}\right)$ at rest were obtained before and during four reactions. The $\mathrm{DL}_{\mathrm{co}}$ fell in all reactions, if the resting ventilation at the time of testing remained approximately the same as before.

EXTRACTS OF FUNGI Inhalation tests with aerosols of the extracts of fungi shown in Table VIII were all negative. The patients tested had reacted to the same, or lower, dosages of mouldy hay extract as these extracts.

\section{T A B LE VIII}

SUMMARY OF INHALATION TESTS ON FARMER'S LUNG PATIENTS WITH EXTRACTS OF FUNGI AND OTHER ALLERGENS

(No farmer's lung patient reacted to them)

\begin{tabular}{|c|c|c|c|}
\hline Extract & $\begin{array}{l}\text { No. of } \\
\text { Farmer's } \\
\text { Lung Patients } \\
\text { Tested }\end{array}$ & $\begin{array}{l}\text { No. of These } \\
\text { Farmer's Lung } \\
\text { Patients who } \\
\text { Reacted to } \\
\text { Mouldy Hay } \\
\text { Extract in the } \\
\text { Same or } \\
\text { Lower Dosage }\end{array}$ & $\begin{array}{l}\text { Acute Reactions } \\
\text { Produced in } \\
\text { Asthmatics } \\
\text { (number) }\end{array}$ \\
\hline $\begin{array}{l}\text { A. fumigatus } \\
\text { A. terreus } \\
\text { A. niger } \\
\text { A. nidulans } \\
\text { A. flavus } \\
\text { Penicillium } \\
\text { Mucor } \\
\text { Candida albicans } \\
\text { Alternaria }\end{array}$ & $\begin{array}{r}15 \\
5 \\
5 \\
5 \\
5 \\
15 \\
14 \\
6 \\
15\end{array}$ & $\begin{array}{r}11 \\
3 \\
3 \\
3 \\
3 \\
12 \\
11 \\
5 \\
12\end{array}$ & 17 \\
\hline $\begin{array}{l}\text { Cladosporium } \\
\text { herbarum } \\
\text { Grass pollen } \\
\text { House dust }\end{array}$ & $\begin{array}{l}15 \\
15 \\
15\end{array}$ & $\begin{array}{l}12 \\
12 \\
12\end{array}$ & $\begin{array}{r}3 \\
20 \\
4\end{array}$ \\
\hline
\end{tabular}

${ }^{1}$ A total of 38 'allergic' asthmatics was studied

EXTRACTS OF MOULDY HAY DUST FRACTIONS A patient inhaled aerosols of $1 \% \mathrm{w} / \mathrm{v}$ extracts of each of the fractions of mouldy hay dust for up to six minutes on different days (Table IX). With this dosage of extract, reactions occurred after the 'coarse' and 'extra-coarse' extracts were inhaled, but not after the 'fine' and 'medium'. Similar aerosols of extracts of the 'fine' and 'medium' fractions produced no reactions in another patient when they were inhaled for five minutes. A reaction did occur, however, when he inhaled a $1 \% \mathrm{w} / \mathrm{v}$ extract of the unfractionated mouldy hay. 
T A B LE I X

\begin{tabular}{|c|c|c|c|c|}
\hline \multicolumn{5}{|c|}{$\begin{array}{l}\text { SUMMARY OF INHALATION TESTS ON A FARMER'S } \\
\text { LUNG PATIENT WITH } 1 \% \text { W/V EXTRACTS OF } \\
\text { MOULDY HAY FRACTIONS }\end{array}$} \\
\hline $\begin{array}{l}\text { Hay fraction } \\
\text { Approx. } \\
\text { particle size }\end{array}$ & $\begin{array}{l}\text { Fine } \\
\text { Up to } 5 \mu\end{array}$ & $\begin{array}{l}\text { Medium } \\
\text { Up to } 20 \mu\end{array}$ & $\begin{array}{l}\text { Coarse } \\
\text { Up to } 200 \mu\end{array}$ & $\begin{array}{l}\text { Extra coarse } \\
\text { Over } 200 \mu\end{array}$ \\
\hline $\begin{array}{l}\text { Main } \\
\text { constituents }\end{array}$ & $\begin{array}{l}\text { Actino- } \\
\text { mycetes } \\
\text { (Strepto- } \\
\text { myces), } \\
\text { bacteria, } \\
\text { small fungal } \\
\text { spores, e.g., } \\
\text { Aspergillus }\end{array}$ & $\begin{array}{l}\text { Monoto- } \\
\text { spora, } \\
\text { small hyphal } \\
\text { fragments }+ \\
\text { constituents } \\
\text { of fine } \\
\text { fraction }\end{array}$ & $\begin{array}{l}\text { Small plant } \\
\text { fragments, } \\
\text { pollen } \\
\text { fragments, } \\
\text { fungal spores } \\
\text { and hyphae } \\
\text { (especially } \\
\text { Mucor) + } \\
\text { constituents } \\
\text { of fine and } \\
\text { medium } \\
\text { fractions }\end{array}$ & $\begin{array}{l}\text { Large plant } \\
\text { fragments } \\
\text { and all the } \\
\text { constituents } \\
\text { s of the } \\
\text { previous } \\
\text { fractions }\end{array}$ \\
\hline $\begin{array}{l}\text { Time extract } \\
\text { inhaled } \\
\text { Symptoms } \\
\text { after }\end{array}$ & 6 minutes & 6 minutes & 6 minutes & 6 minutes \\
\hline $\begin{array}{l}\text { inhalation } \\
\text { Crepitations } \\
\text { on chest }\end{array}$ & 0 & 0 & ++ & $+t$ \\
\hline $\begin{array}{l}\text { auscultation } \\
\text { Fever } \\
\text { Changes in }\end{array}$ & $\begin{array}{l}0 \\
0\end{array}$ & $\begin{array}{l}0 \\
0\end{array}$ & $100.6^{\circ} \mathrm{F}$ & $\stackrel{+}{100 \cdot 2^{\circ} \mathrm{F} .}$ \\
\hline $\begin{array}{l}\text { Jung func- } \\
\text { tion tests } \\
\text { Reaction }\end{array}$ & $\begin{array}{l}0 \\
\text { No }\end{array}$ & $\begin{array}{l}0 \\
\text { No }\end{array}$ & $\begin{array}{l}++ \\
\text { Yes }\end{array}$ & $\begin{array}{l}++ \\
\text { Yes }\end{array}$ \\
\hline
\end{tabular}

OTHER HAY EXTRACTS Inhalation tests with aerosols of the 'good' hay extracts and preparations from them (Table $X$ ) did not produce reactions in farmer's lung patients. These patients had previously reacted to a smaller dose of mouldy hay extract.

\section{T A B LE X}

INHALATION TESTS WITH VARIOUS HAY EXTRACTS IN FARMER'S LUNG PATIENTS WHO REACTED TO MOULDY HAY EXTRACT

\begin{tabular}{lc} 
'Good hay' & $\begin{array}{l}\text { No. of } \\
\text { Patients } \\
\text { Studied }\end{array}$ \\
\hline Autoclaved 'good hay' & 4 \\
'Good hay' inoculated with A. fumigatus & 4 \\
'Good hay' inoculated with Mucor (sp.) & 2 \\
All were negative & 2
\end{tabular}

CORTICOSTEROIDS AND FARMER'S LUNG REACTIONS The effect of mouldy hay extract on a patient while receiving corticosteroid therapy was studied (Table XI). The patient inhaled an aerosol of a $1 \% \mathrm{w} / \mathrm{v}$ extract of mouldy hay for five minutes and a reaction occurred. A further reaction was seen the following day when the same extract was inhaled for two minutes. The patient had not therefore become refractory to the extract after the first inhalation. Prednisolone therapy, $40 \mathrm{mg}$. daily, was started. A reaction was not obtained
T A B L E X I

EFFECT OF PREDNISOLONE ON SENSITIVITY TO INHALATION OF MOULDY HAY EXTRACT

\begin{tabular}{|c|c|c|c|c|}
\hline \multirow{4}{*}{ 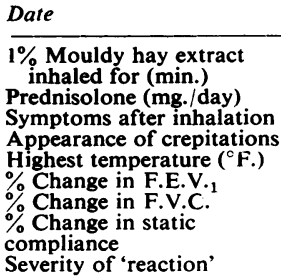 } & 12.11 .59 & 13.11 .59 & 15.11 .59 & 15.5 .60 \\
\hline & 5 & 2 & 5 & 6 \\
\hline & $\begin{array}{r}0 \\
++ \\
++ \\
102 \\
-18 \\
-17\end{array}$ & $\begin{array}{r}0 \\
+ \\
+ \\
100 \\
-10 \\
-3\end{array}$ & $\begin{array}{c}40 \\
0 \\
0 \\
98 \cdot 0 \\
+2 \\
0\end{array}$ & $\begin{array}{c}0 \\
++ \\
+ \\
101 \cdot 6 \\
-15 \\
-26\end{array}$ \\
\hline & $\begin{array}{r}-80 \\
++\end{array}$ & $\begin{array}{r}-68 \\
+\end{array}$ & $\begin{array}{r}+7 \\
+7 \\
0\end{array}$ & $\begin{array}{r}57 \\
++\end{array}$ \\
\hline
\end{tabular}

after the inhalation of the same extract for five minutes when the patient was having this treatment. Later, when corticosteroid therapy had been discontinued, a reaction was again produced by mouldy hay extract. Protection from the acute effects of mouldy hay extract seems to have been given to this patient by corticosteroid therapy. This information was of value in his later management.

\section{INHALATION TESTS ON CONTROLS}

Three control subjects inhaled mouldy hay dust for 20 minutes from a face mask but no reactions were produced. Inhalation tests with mouldy hay extracts were negative in 20 control subjects. (Seventy-four tests were made, and the dosage of the extract used was either the same as, or larger than, that which had produced reactions in farmer's lung patients.) One control (myself) was given 20 weekly exposures to mouldy hay extract, each for 5 minutes. No reactions occurred.

\section{INHALATION TESTS ON ALLERGIC ASTHMATICS}

A 50-year-old farmer, who suffered from asthma, thought that his symptoms became worse after exposure to mouldy hay dust. He had positive skin tests to extracts of Aspergillus and Penicillium. After the inhalation of a $1 \% \mathrm{w} / \mathrm{v}$ mouldy hay extract for five seconds, he noticed slight nasal irritation, dyspnoea, and wheeze within minutes. Auscultation of his chest at this time showed that rhonchi had appeared but no crepitations were heard. Both his F.E.V., and F.V.C. fell (Fig. 7). The inhalation of Coca (Carbol-saline) solution for five seconds before this test had no effect. Similar symptoms, signs, and lung function changes were seen after inhalation tests with extracts of $\boldsymbol{A}$. fumigatus and Penicillium (Figs. 8 and 9). After the inhalation of Aspergillus extract there appeared to be a recurrence of wheeze six hours later, suggesting that a delayed reaction 
occurred. Mouldy hay contains the fungi Penicillium and Aspergillus. It is probable that mouldy hay produced asthma in this patient because he was hypersensitive to these fungi.

Similar results were obtained in 30 inhalation tests on 17 asthmatic patients with skin hypersensitivity to Aspergillus. Increased wheeze occurred within minutes after the inhalation of Aspergillus extract and the wheeze recurred six to eight hours later in 12 reactions. General symptoms were not prominent with the dosage of extract inhaled. A mean fall in F.E.V. ${ }_{1}$ of $38 \%$ and in F.V.C. of $30 \%$ occurred.

The effects of isoprenaline on 20 grass pollen sensitive asthmatics, after exposure to grass pollen extract, are shown in Table XII. Marked improvement occurred, contrasting with the reactions obtained after the inhalation of mouldy hay extract by farmer's lung patients.

Table XIII shows some lung function changes during three inhalation tests in asthmatics with appropriate allergens. It is seen that static lung compliance falls much less than F.E.V..$_{1}$ and F.V.C.

\section{DISCUSSION}

Skin tests with extracts of mouldy hay and fungi did not distinguish farmer's lung patients from controls. Fuller (1953) and Studdert (1953) made similar observations. Inhalation tests with mouldy hay dust had never been described when this work was started. Since

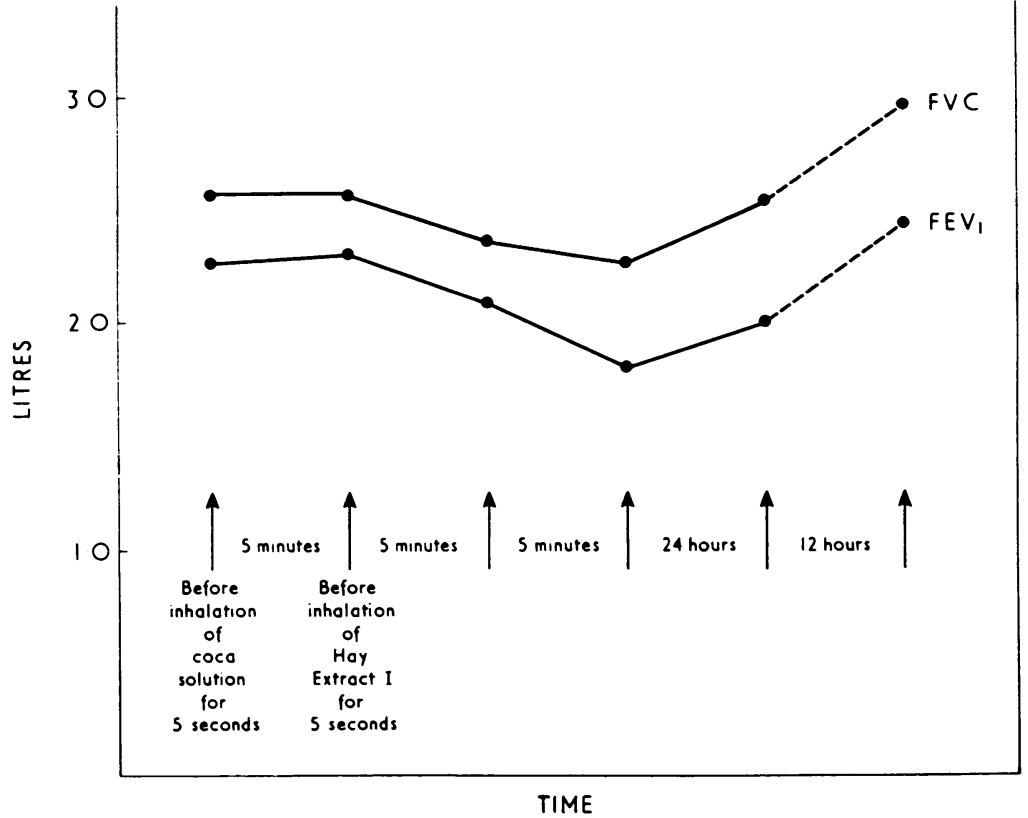

FIG. 7. F.E.V. ${ }_{1}$ and F.V.C. measurements after inhalation of a mouldy hay extract and also carbol saline (Coca) control (asthmatic farmer).

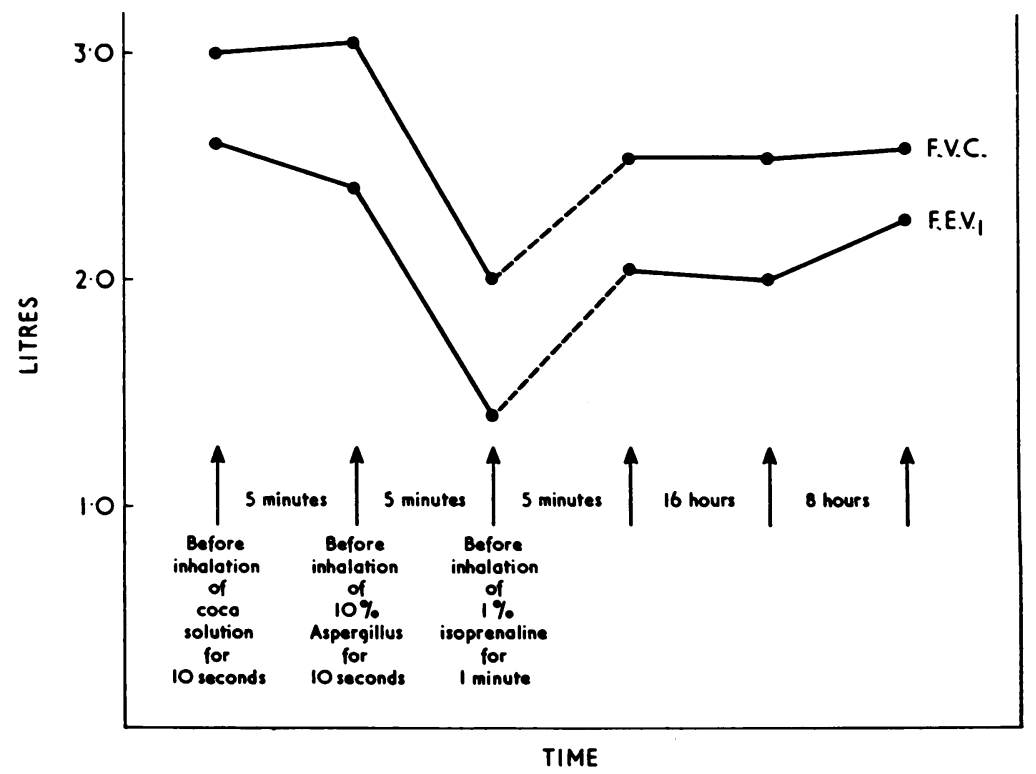

FIG. 8. F.E.V.1 and F.V.C. measurements after inhalation of Aspergillus extract and also carbol saline (Coca) control (same patient as in Figs. 7 and 9). 


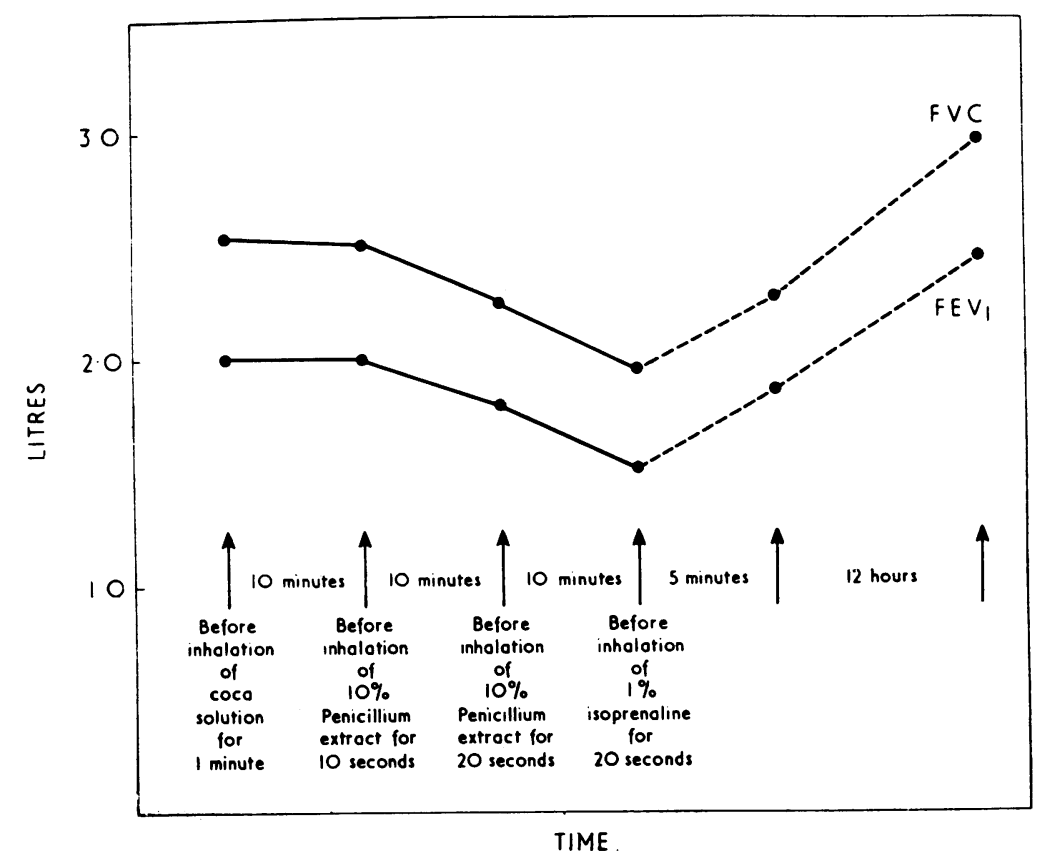

FIG. 9. F.E.V.1 and F.V.C. measurements after inhalation of Penicillium extract and also carbol saline (Coca) control (same patient as in Figs. 7 and 8).

\section{T A B LE XI I}

THE EFFECT OF ISOPRENALINE ${ }^{1}$ ON REACTIONS

\begin{tabular}{|c|c|c|c|c|}
\hline \multicolumn{2}{|c|}{ Subjects Studied } & \multirow{2}{*}{$\begin{array}{l}\text { Reaction } \\
\text { Induced } \\
\text { by Aerosol of }\end{array}$} & \multicolumn{2}{|c|}{$\%$ Change in } \\
\hline Diagnosis & No. & & F.E.V.1 & F.V.C. \\
\hline $\begin{array}{l}\text { Farmer's lung } \\
\text { Asthma }\end{array}$ & $\begin{array}{r}6 \\
20\end{array}$ & $\begin{array}{l}\text { Mouldy hay extract } \\
\text { Grass pollen extract }\end{array}$ & $\begin{array}{r}+5 \\
+107\end{array}$ & $\begin{array}{r}+3 \\
+66\end{array}$ \\
\hline
\end{tabular}

then, Baldus and Peter (1960) and Staines and Forman (1961) have described a total of three patients who became ill after the experimental inhalation of hay dust. Two of these patients were breathless for days. The inhalation tests with mouldy hay dust which I described produced a mild positive reaction in one patient which lasted hours.

Inhalation tests with aerosols of water-soluble, Seitz-filtered extracts of mouldy hay have not been described previously. The clinical features during the reactions in these tests were very similar to (a) those described in the acute illness of farmer's lung, $(b)$ those produced in the inhalation tests with crude mouldy hay dust, and $(c)$ the illness these patients had suffered previously after contact with mouldy hay in their work. Seitz-filtered extracts of mouldy hay will thus have the same acute effects on farmer's lung patients as crude mouldy hay dust. Williams and Mulhall (1956) suggested that the mechanical occlusion of the respiratory
TABLE XIII

INHALATION TESTS ON ASTHMATICS

\begin{tabular}{|c|c|c|c|c|}
\hline Patient & Extract & $\begin{array}{l}\% \text { Change } \\
\text { in Static } \\
\text { Compliance }\end{array}$ & $\begin{array}{l}\% \text { Change } \\
\text { in F.E.V.1 } \\
e\end{array}$ & $\begin{array}{l}\% \text { Change } \\
\text { in F.V.C. }\end{array}$ \\
\hline $\begin{array}{l}1 \\
2 \\
3\end{array}$ & $\begin{array}{l}10 \% \text { A. fumigatus } \\
1 \% \text { Grass pollen } \\
1 \% \text { Grass pollen } \\
\text { Mean }\end{array}$ & $\begin{array}{r}-10 \\
-5 \\
-12 \\
-9\end{array}$ & $\begin{array}{l}-44 \\
-30 \\
-36 \\
-37\end{array}$ & $\begin{array}{l}-34 \\
-29 \\
-26 \\
-30\end{array}$ \\
\hline
\end{tabular}

bronchioles by hay and fungus spores might be important in the causation of the acute symptoms of farmer's lung. Pickworth (1961) stated that such mechanical interference may be due to the swelling and germination of the spores of the fungi. As nebulized mists of mouldy hay extracts, in which all the solid particles were smaller than $0.7 \mu$, produced the same symptoms and signs of the acute illness as the crude hay, the mechanical blocking effect of hay particles on the smaller air passages must clearly be unimportant. The chemical properties of the dust and its extract seem much more important.

Moderate reductions in ventilatory function were noted in the positive inhalation tests with mouldy hay reported by Baldus and Peter (1960), and by Staines and Forman (1961). The main changes found in the farmer's lung reactions I studied may be summarized as a marked fall in static lung compliance, a less marked though 
definite fall in ventilatory function with no significant airway obstruction which could be reversed by isoprenaline, some impairment in diffusing capacity, and an increase in minute volume. These changes are compatible with a functional defect in the alveoli or respiratory bronchioles. There is no evidence of obstruction in the larger pulmonary airways. The clinical findings of crepitations rather than rhonchi on chest auscultation support this.

Mouldy hay or its extract produced acute illnesses in farmer's lung patients but not in the controls. It does not appear therefore to act as a non-specific pulmonary irritant, as suggested by Studdert (1953), or as a toxin, as proposed by Frankland and Hamilton (1958). This specificity of mouldy hay extract in producing acute illnesses in farmer's lung patients only, suggests that these patients are hypersensitive either to it or some constituent of it. Most farmer's lung patients studied had worked intermittently with mouldy hay for many years before clinical evidence of the disease was seen. A long period of exposure may therefore be necessary before sensitization occurs. It is not known whether sensitization to mouldy hay occurs only in certain people or whether it may occur in anyone, provided there is adequate exposure to the dust. An outbreak of 'weaver's cough', a disease similar clinically to farmer's lung, was due to the use of tamarind seed powder as a sizing agent in the weaving industry (Murray, Dingwall-Fordyce, and Lane, 1957). Inhalation tests with this substance reproduced the illness in patients with this condition but not at first in controls (Tuffnell and Dingwall-Fordyce, 1957). Some controls eventually reacted after repeated exposures to the dust. The ease with which this could be done varied. It is possible that some of the controls used in the present investigation may have behaved similarly with repeated exposures to mouldy hay dust. Certainly my 20 weekly exposures failed to produce clinical evidence of sensitization to it.

If hypersensitivity to mouldy hay is responsible for the acute illnesses of farmer's lung then antibodies to mouldy hay may be present in farmer's lung patients. Pepys, Riddell, Citron, and Clayton (1962) have shown that precipitins to mouldy hay extracts are present in the sera of farmer's lung patients. Rankin (1962) described similar precipitins which seemed specific for farmer's lung patients. Parish (1961, and to be published) produced reactions similar clinically to farmer's lung in guinea-pigs and rabbits previously sensitized to mouldy hay dust, by further exposure to the dust. Only animals with serum precipitins to mouldy hay reacted. The histological changes seen in the lungs of farmer's lung patients are similar to those described in rats after the intratracheal injection of rabbit anti-lung serum (Read, 1958). This supports the theory that farmer's lung is due to hypersensitivity.

The difference between the reactions seen in farmer's lung patients, using mouldy hay extracts, and those described in allergic asthmatics, using appropriate allergens, reflects some of the differences between farmer's lung and asthma. Fuller (1953) stressed the clinical differences. Asthmatic reactions usually appear minutes and farmer's lung reactions hours after exposure. General reactions characterized by nausea, flushing, pallor, and faintness occur in asthmatics but are uncommon if the quantities of allergen used produce mild respiratory symptoms only. The farmer's lung reactions described all showed marked general disturbances although respiratory distress was slight. Rhonchi appeared in the asthmatic, while crepitations were heard in the farmer's lung reaction. In both there was a fall in vital capacity. In the asthmatic it was due to reversible bronchial airway obstruction whereas in farmer's lung it was due mainly to a reduction in pulmonary compliance. It seems that the site of the pathological processes is different in the two diseases. The asthmatic reaction involves the bronchial and bronchiolar airways but farmer's lung the more peripheral passages.

Mouldy hay contains quantitatively more fungi and their spores than 'good' hay (Gregory and Bunce, 1961). It produces the clinical features of farmer's lung whereas 'good' hay does not. Thus fungi have often been postulated as the cause of farmer's lung. Quinlan and Hiltz (1959) called the disease 'mould spore pneumoconiosis'. The fungi found in mouldy hay include genera of Aspergillus, Penicillium, Mucor, and Monotospora as well as actinomycetes and bacteria. Inhalation tests with aerosols of extracts of the mouldy hay fungi have not previously been reported in farmer's lung patients. The tests described here showed that extracts of the main hay fungi individually (Table VIII) did not produce the acute farmer's lung illness, whereas smaller exposures to mouldy hay extracts in the patients tested were effective. These fungi and their spores do not therefore cause the acute illness of farmer's lung. C. albicans was not isolated from the mouldy specimens examined, was seen inconsistently in the sputum specimens, and extracts of it produced non-specific skin reactions in farmer's lung patients. Törnell (1946), Zettergren (1950), 
Soucheray (1954), Helms (1959), and Uyterlinde (1959) have suggested that $C$. albicans might be the cause of farmer's lung. The failure of its extract to reproduce the acute farmer's lung illness, while smaller quantities of mouldy hay extract were effective, shows that it has no direct causative effect in this illness.

Although inhalation tests with extracts of Aspergillus and Penicillium did not produce farmer's lung reactions, they did produce wheeze in certain asthmatics. An asthmatic farmer described here (Figs. 7, 8, and 9) had subjective and objective evidence of bronchospasm after the inhalation of extracts of mouldy hay, Penicillium, and Aspergillus. Credille (1933) described an asthmatic farmer with positive skin reactions to A. fumigatus extracts, who wheezed whenever he opened his silo. Allergic pulmonary aspergillosis (Hinson, Moon, and Plummer, 1952) resembles farmer's lung as, in both, dyspnoea and fever may follow exposure to mouldy hay. The former is associated with wheeze, a previous allergic history, the expectoration of plugs, blood and sputum eosinophilia, and transient localized pulmonary radiological infiltrations. These patients react to extracts of Aspergillus. Thus skin tests produce weals, inhalation tests increase bronchial airway obstruction, and their serum contains antibodies which give precipitation reactions (Citron and Pepys, 1958 ; Pepys et al., 1959). Confusion still exists in distinguishing farmer's lung from pulmonary aspergillosis. Jackson and Yow (1961) described two patients with 'farmer's lung' or 'pulmonary infiltration with eosinophilia'. Patient I had a past history of nasal allergy, a marked blood eosinophilia, Aspergillus persistently grown on sputum culture, and a chest radiograph compatible with pulmonary aspergillosis. No mention is made of dyspnoea and wheeze but the onesecond timed vital capacity was $44 \%$ of the total vital capacity, suggesting that bronchial airway obstruction was present. Patient II had wheeze, blood eosinophilia, and brown sputum, and here again the chest radiograph was compatible with pulmonary aspergillosis. Similarly, Rongières and Pesle (1961) describe a patient (Observation No. 2 -Mme. T. Lucienne) with wheeze, who expectorated brown solid plugs containing Aspergillus, had a blood eosinophilia, and whose bronchogram showed bronchiectasis. These patients all developed symptoms after exposure to mouldy vegetable matter. Although the diagnosis in these patients has been 'farmer's lung' or 'maladie des batteurs', the descriptions given would fit that of allergic pulmonary aspergillosis.
T A B LE XIV

COMPARISON OF FEATURES OF ALLERGIC PULMONARY ASPERGILLOSIS WITH THOSE OF FARMER'S LUNG

\begin{tabular}{|c|c|c|}
\hline & $\begin{array}{l}\text { Allergic Pulmonary } \\
\text { Aspergillosis }\end{array}$ & Farmer's Lung \\
\hline $\begin{array}{l}\text { Dyspnoea after inhala- } \\
\text { tion of mouldy hay } \\
\text { dust or its extract } \\
\text { Wheeze } \\
\text { Fever } \\
\text { Sputum (Aspergillus } \\
\text { may be isolated from } \\
\text { either) }\end{array}$ & $\begin{array}{l}\text { Immediate (possibly } \\
\text { a recurrence a few } \\
\text { hours later) } \\
+ \\
+ \\
\text { Brown plugs often } \\
\text { present }\end{array}$ & $\begin{array}{l}\text { Usually a few } \\
\text { hours later } \\
0 \\
+ \\
\text { Nothing specific }\end{array}$ \\
\hline $\begin{array}{l}\text { Family and past } \\
\text { history of allergic } \\
\text { illnesses }\end{array}$ & Yes & Not usually \\
\hline $\begin{array}{l}\text { Eosinophilia (blood } \\
\text { and sputum) }\end{array}$ & + & 0 \\
\hline $\begin{array}{l}\text { Transient pulmonary } \\
\text { radiographic shadows }\end{array}$ & $\begin{array}{l}\text { Localized (consolida- } \\
\text { tion or collapse } \\
\text { usually) }\end{array}$ & $\begin{array}{l}\text { Diffuse reticulo- } \\
\text { nodular, more } \\
\text { marked in lower } \\
\text { zones }\end{array}$ \\
\hline Prick skin test to & Positive & Negative \\
\hline Prick skin test to & Non-specific & Non-specific \\
\hline $\begin{array}{l}\text { Inhalation test to } \\
\text { mouldy hay extract }\end{array}$ & $\begin{array}{l}\text { Immediate reaction } \\
\text { characterized by } \\
\text { bronchospasm }\end{array}$ & $\begin{array}{l}\text { Usually delayed } \\
\text { reaction character- } \\
\text { ized by a more } \\
\text { peripheral pulmon- } \\
\text { ary reaction } \\
\text { (crepitations rather } \\
\text { than rhonchi) }\end{array}$ \\
\hline $\begin{array}{l}\text { Inhalation test to } \\
\text { Aspergillus extract }\end{array}$ & $\begin{array}{l}\text { Immediate reaction } \\
\text { characterized by } \\
\text { bronchospasm } \pm \\
\text { delayed reaction }\end{array}$ & Negative \\
\hline $\begin{array}{l}\text { Serum precipitins to } \\
\text { Aspergillus extract } \\
\text { Serum precipitins to } \\
\text { hay extract (after } \\
\text { suitable inhibition } \\
\text { tests) } \\
\text { Corticosteroid therapy }\end{array}$ & $\begin{array}{l}0 \\
\text { Improvement }\end{array}$ & $\begin{array}{l}\text { Present } \\
\text { Improvement }\end{array}$ \\
\hline
\end{tabular}

Table XIV shows the main differences between the two conditions.

The inhalation tests with Seitz-filtered extracts of fractionated mouldy hay dust (Table VIII) showed that the substance responsible for the acute reactions was found in the 'coarse' and 'extra coarse' fractions rather than in the 'fine' and 'medium'. The former fractions differed in composition from the latter as they contained much more plant fragments, hay fibre, grass pollen, and some mycelium of fungi. Now similarly prepared extracts of grass pollen were shown to produce hay fever and asthma in certain asthmatics, but could not produce the farmer's lung type of reaction in farmer's lung patients. Extracts of the identified moulds and spores were tested separately and could not produce farmer's lung reactions. The other constituents of the 'coarse' and 'extra coarse' fractions which were not present in any quantity in the 'fine' and 'medium' fractions were plant fragments and hay fibre, and therefore these are most likely to contain the active substance. The failure of the 'fine' and 'medium' fractions, 
which consisted mainly of bacteria, actinomycetes, Monotospora, and other fungal spores to produce reactions, makes it unlikely that these cause the acute illness of farmer's lung directly.

It might seem odd that reactions were only produced in this experiment by the substances extracted from the larger particles (above $20 \mu$ in size). The reactions described in farmer's lung patients suggested that the alveoli and terminal bronchioles were affected rather than the larger airways. In the natural unextracted state it would be difficult for the larger particles to reach the small airways where these reactions seem to occur. Foreign materials of comparable size to the larger particles have been seen in the giant cells in lung biopsy specimens of farmer's lung patients (Totten and others, 1958). If the larger particles are inhaled, the active substances may be dissolved in the bronchial secretions and the extracts either absorbed or aspirated peripherally into the alveoli and bronchioles to produce their effects. It is more likely, however, that the active substance is concentrated in the coarser particles consisting of the plant fibre, but fragments are also present in small quantities in the 'fine' and 'medium' fractions. In the experiment described the quantity of plant fibre in the 'fine' and 'medium' extracts was insufficient to produce a reaction after six minutes but may have been sufficient after a few hours' exposure, as often occurs in threshing.

As the evidence presented is against hay fungi and bacteria causing the acute illness of farmer's lung, attention must be given to the hay fibre. Inhalation tests with 'good' hay extracts failed to produce a reaction whereas those with mouldy hay did. It is possible that the hay bacteria and fungi act on the hay fibre producing the substances responsible for farmer's lung. 'Good' hay inoculated artificially with Aspergillus and Mucor failed to produce reactions. When hay becomes mouldy, the heat generated may cause chemical alteration of the hay fibre. Inhalation tests with autoclaved 'clean' hay extracts were also negative, however. The actual process which takes place in the hay substance, converting 'clean' hay into 'farmer's lung-producing' hay, is still not explained.

Pepys and others (1962) found that heating good hay and then inoculating it with fungi produced extracts which showed increased antigenicity for farmer's lung sera. This resembles the natural process in the formation of mouldy hay in the course of which overheating of the hay occurs. This suggests that the combined process may be involved in making 'farmer's lung-producing' hay from 'good' hay.
The acute illness of farmer's lung usually improves if further exposure to mouldy hay dust is avoided. The clinical assessment of various treatments is therefore difficult. Corticosteroid therapy has been used in this disease by Dickie and Rankin (1958). In uncontrolled observations they thought this treatment beneficial. The fact that prednisolone protected a patient from an induced reaction is useful confirmatory evidence of the value of the drug in this disease. Corticosteroid therapy cannot, however, be regarded as a substitute for the prevention of exposure of the patient to mouldy hay dust. The failure of isoprenaline to produce significant objective improvement in the acute reactions studied, shows that this drug is of little value in treatment.

Farmer's lung must be recognized early so that further exposure of the patient to mouldy hay dust may be prevented. As this may result in a change of occupation and possible economic hardship, it is important that the diagnosis is correct. A history of respiratory symptoms after exposure to mouldy vegetable dust is important in making this diagnosis. Difficulty may arise as other respiratory disease, e.g., bronchitis, asthma, and allergic pulmonary aspergillosis, may all be worse after exposure to a dusty atmosphere. Further, the occurrence of symptoms hours after exposure may make it difficult for the patient to correlate his illness with his work. Any confirmatory diagnostic evidence is therefore of value.

Skin tests with mouldy hay extracts are unhelpful in diagnosis. Skin tests with extracts of the hay fungi are only important in so far as positive tests make a diagnosis of asthma more likely. Inhalation tests with mouldy hay dust or extracts were able to reproduce the features of the acute illness in 11 (possibly 12) of the 15 patients studied. The test appears to be specific, reproducible, and safe. The dosage of mouldy hay can be gauged more accurately if aerosols of extracts of mouldy hay are used instead of the crude hay. Because of the marked individual variation in sensitivity, minute doses should be given at first and these should be gradually increased on different days. As close observation for several hours after the test is essential, the tests should be made in hospital. There is usually no clinical doubt when a test is positive. A repetition of the test using a control solution, unknown to the patient, would then add further weight to the diagnosis if negative. The discomfort during the tests should last a few hours only. If symptoms are produced by the test their relation to mouldy hay dust can be stressed to the patient. 


\section{SUMMARY}

The acute illnesses, which follow the inhalation of mouldy hay dust in farmer's lung patients, were produced by aerosols of water-soluble, Seitzfiltered extracts of mouldy hay. The mechanical effects of hay particles were thus not responsible for these illnesses.

Inhalation tests with mouldy hay and its extract produced reactions in 12 of 15 farmer's lung patients but not in 20 controls. Farmer's lung patients thus appear hypersensitive to mouldy hay extract.

Reactions were characterized by a delay of several hours before onset, a marked fall in static lung compliance, a less marked but definite fall in ventilatory function, a fall in pulmonary diffusing capacity, an increase in minute volume, and no evidence of bronchial airway obstruction reversible with isoprenaline. A functional defect in the alveoli and respiratory bronchioles was suggested by these findings. This contrasted with inhalation tests on 38 allergic asthmatics with appropriate antigens, in whom the immediate onset of bronchospasm appeared.

Inhalation tests with extracts of the mouldy hay fungi and fractionated mouldy hay suggested that the fungi and bacteria were not directly responsible for reactions. The other vegetable material, altered in some way by the hay becoming mouldy, seemed more likely to cause the illness.

Prednisolone protected a patient from a reaction.

Inhalation tests with mouldy hay extracts were of value in the diagnosis of farmer's lung, but skin tests were of no value.

The generous encouragement and advice of Professor J. G. Scadding and Dr. K. M. Citron is acknowledged. Grateful acknowledgment is also made to Dr. C. J. Fuller and Dr. J. L. Livingstone, who referred many of the farmer's lung patients studied; to Dr. R. W. Riddell, Dr. Y. M. Clayton, and Dr. P. H. Gregory for advice and help on the mycological aspects of the work, and to Dr. F. J. Prime and the staff of the Pulmonary Function Laboratory of the Institute of Diseases of the Chest, Brompton Hospital, for help with the pulmonary function studies.

\section{REFERENCES}

Baldus, W. P., and Peter, J. B. (1960). New Engl. J. Med., 262, 700. Bernstein, L., D'Silva, J. L., and Mendel, D. (1952). Thorax, 7, 255. Campbell, J. M. (1932). Brit. med. J., 2, 1143.

Citron, K. M., and Pepys, J. (1958). In Fungous Diseases and Their Treatment, edited by Riddell, R. W., and Stewart, G. T., p. 134. Butterworth, London.

Cooper, I. A., and Greenaway, T. M. (1961). Med. J. Aust., 2, 980. Credille, B. A. (1933). J. Mich. med. Soc., 32, 167.

Davies, H., Williams, J., and Wood, P. (1962). Brit. Heart J., 24, 129. Dickie, H. A., and Rankin, J. (1958). J. Amer. med. Ass., 167, 1069.

Duncan, J. T.(1945). Brit. med. J., 2, 715.

Fawcitt, R. (1936a). Brit. J. Radiol., 9, 172

(1936b) lbid., $9,354$.

- (1938a). Amer. J. Roentgenol., 39, 19.

- (1938b). Brit. J. Radiol. 11, 378.

Frank, R. C. (1958). Amer. J. Roentgenol., 79, 189.

Frankland, A. W., and Hamilton, E. D. (1958). Allergie u. Asthma,

Fuller, C. J. (1953). Thorax, 8, 59.

(1958). In Fungous Diseases and Their Treatment, edited by Riddell, R. W., and Stewart, G. T., p. 138. Butterworth, London.

Gregory, P. H., and Bunce, M. E. (1961). Acta allerg. (Kbh.), 16, 74.

Helms, P. (1959). Ugeskr. Laeg., 121, 466.

Hinson, K. F. W., Moon, A. J., and Plummer, N. S. (1952). Thorax, 7, 317.

Jackson, D., and Yow, E. (1961). New Engl. J. Med., 264, 1271.

Macnamara, J., Prime, F. J., and Sinclair, J. D. (1959). Thorax, 14,166 .

Murray, R., Dingwall-Fordyce, J., and Lane, R. E. (1957). Brit. J. industr. Med., 14, 105.

Parish, W. E. (1961). Acta allerg. (Kbh.), 16, 78.

Pepys, J., Riddell, R. W., Citron, K. M., and Clayton, Y. M. (1962). Thorax, 17, 366. $80,167$.

Pernis, B., Vigliani, E. C., Cavagna, C., and Finueli, M. (1961). Brit. J. industr. Med. 18, 120.

Pickworth, K. H. (1961). Lancet, $2,660$.

Quinlan, J. J., and Hiltz, J. E. (1959). Canad. med. Ass. J., 80, 261.

Rankin, J. (1962). Tubercle (Lond.), 43, 331.

Read, J. (1958). J. Path. Bact., 76, 403.

Rongières, A., and Pesle, G. D. (1961). J. franç. Méd. Chir. thor., 15, 73 .

Seal, R. (1962). Tubercle (Lond.), 43, 330.

Soucheray, P. H. (1954). Minn. med. 37, 251.

Staines, F. H., and Forman, J. A. S. (1961). J. Coll. gen. Practit., 4, 351 .

Studdert, T. C. (1953). Brit. med. J., 1, 1305.

Törnell, E. (1946). Acta med. scand., 125, 191.

Totten, R. S., Reid, D. H. S., Davis, H. D., and Moran, T. J. (1958). Amer. J. Med., 25, 803.

Tuffnell, P. G., and Dingwall-Fordyce, I. (1957). Brit. J. industr. Med. $14,250$.

Uyterlinde, B. (1959). Ned. T. Geneesk., 103, 457.

Williams, D. I., and Mulhall, P. P. (1956), Brit, med. J., 2,1216

Williams, D. I., and Mulhall, P. P. (1956). Brit. med.

Wright, B. M. (1955). J. Physi (1958). Lancet, 2, 24

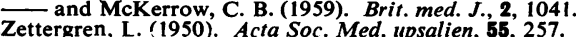

